\title{
Comparative Emission Study On Gasoline Vehicles
}

\author{
Okoli S.O. ${ }^{1}$, Achebe C.H. ${ }^{2}$, and Anosike B.N. ${ }^{2}$ \\ ${ }^{I}$ Department of Mechanical Engineering Technology, Akanu Ibiam Federal Polytechnic, Unwana, Ebonyi State \\ ${ }^{2}$ Department of Mechanical Engineering, Nnamdi Azikiwe University, Awka, Anambra State
}

\begin{abstract}
This research measured and compared the emission results of high mileage cars and sport utility vehicles. It further investigated the emission contents of car and SUVs exhaust of low mileage and high mileage at idle condition of the engine, paying more regards to harmful pollutants. The analysis showed that significant amounts of CO, NOx, HC, were emitted in cars and SUVs with high mileage and high engine capacity compared to ones with low mileage and lower engine capacity. The six vehicles studied were; four high mileage and two low mileage vehicles $(111,000 \mathrm{~km}-113,000 \mathrm{~km}$ and $14,000 \mathrm{~km}-16,000 \mathrm{~km}$ respectively) which is the range of passenger cars predominantly used in Nigeria. Tests showed a drop in $\mathrm{CO}$ in percentage from 0.07 , 0.06, 0.02, 0.02 to 0.027 and 0.02 for SUVs A and B, Cars A and B, SUV C and Car C respectively at engine speed of 1000rpm. The result further revealed that low mileage vehicles emit less harmful pollutants than their high mileage counterparts and that engine load was equally a contributing factor in exhaust emission of gasoline vehicles at idle conditions.
\end{abstract}

Keywords: Catalytic converters, Engine capacity, Exhaust emission, Greenhouse gases, Fuel consumption, Pollutants, Power rating.

\section{INTRODUCTION}

Emission is the most common problem associated with vehicle idling in urban driving. The automobiles in Nigeria are mostly fairly used vehicles (high-mileage vehicles) yet with the growing fleet of vehicles and escalating amount of time spent in traffic by the drivers and passengers the emissions seem to increase. These vehicles usually consume more fuel and emit more pollutants as a result of operational conditions. There is a hierarchy of emission estimation techniques (EETs) ranging broadly from the most accurate and site-specific to generic and least accurate. These are namely: direct emission measurement; indirect measurement; mass balance calculation; emission factors; engineering judgment; models and physiochemical relationships (Ademuyiwa, 2009). Vehicle characteristics such as engine size, power rating and weight are also factors influencing fuel consumption and emission rates (Ajayi and Dosunmu, 2010). Generally, vehicles with large engine sizes (2.0L and above) emit more pollutants than vehicles with small engines, and large engine sizes are commonly accompanied with high maximum-horsepower (Ajayi and Dosunmu, 2010). Ambient temperature is an important parameter affecting both exhaust and evaporative emissions. Previous studies, (Kuhns et al., 2007 and Chan et al., 2004) commented that older vehicles emitted more pollutants than newer ones. Chan et al., (2004) also observed that the older trucks had higher CO emission factors but lower NOx emission factors due to poor engine combustion associated with their high usage rates and limited maintenance. For engines in idling mode the friction, the heat losses are greater than ones fully warmed and the time required to reach steady-state operating temperature is longer. These factors contribute to a longer period of relatively poor combustion and consequent need for more fuel enrichment (operation with more fuel than required for stoichiometry). The combination of these factors results in higher exhaust concentration of unburnt fuel in the form of hydrocarbon and carbon II oxide. Fossil fuels are the major contributors to urban air pollution and source of greenhouse gases. Due to unabated high emission rates, the ozone layer which plays a critical role in screening harmful ultra violet radiation is depleting thereby allowing the harmful radiation to reach the earth surface. Hence, it is highly desirable to reduce vehicular emissions, more so, as international concerns are being raised for control and restriction and strict environmental legislations.A catalytic converter is a vehicle emissions control device that converts toxic pollutants in exhaust gas to less toxic pollutants by catalyzing a redox reaction (oxidation or reduction). Catalytic converters are used in internal combustion engines fueled by either petrol (gasoline) or diesel - including lean burn engines.

The first widespread introduction of catalytic converters was in the United States automobile market. Manufacturers of 1975 model year equipped gasoline-powered vehicles with catalytic converters to comply with the U.S. Environmental Protection Agency's stricter regulation of exhaust emissions (Vijayan, 2007).

These "two-way" converters combined carbon II oxide (CO) with unburnt hydrocarbons (UHC) to produce carbon IV oxide $\left(\mathrm{CO}_{2}\right)$ and water $\left(\mathrm{H}_{2} \mathrm{O}\right)$ as shown in the equations (1.1) and (1.2). In 1981, two-way catalytic 
converters were rendered obsolete by "three-way" converters that also reduce oxides of nitrogen $\left(\mathrm{NO}_{\mathrm{x}}\right)$ (Roumegoux, 2006). However, two-way converters are still used for lean burn engines.

Oxidation of carbon II oxide to carbon IV oxide:

$$
2 \mathrm{CO}+\mathrm{O}_{2} \quad \rightarrow \quad 2 \mathrm{CO}_{2}
$$

Oxidation of hydrocarbons (unburnt and partially burnt fuel) to carbon IV oxide and water:

$$
\mathrm{C}_{\mathrm{x}} \mathrm{H}_{2 \mathrm{x}+2}+[(3 \mathrm{x}+1) / 2] \mathrm{O}_{2} \rightarrow \quad \mathrm{xCO}_{2}+(\mathrm{x}+1) \mathrm{H}_{2} \mathrm{O}
$$

A three-way catalytic converter has three simultaneous tasks:

Reduction of nitrogen oxides to nitrogen and oxygen:

$$
2 \mathrm{NOx} \rightarrow \mathrm{xO}_{2}+\mathrm{N}_{2}
$$

Oxidation of carbon II oxide to carbon IV oxide:

$$
2 \mathrm{CO}+\mathrm{O}_{2} \rightarrow \quad 2 \mathrm{CO}_{2}
$$

Oxidation of unburnt hydrocarbons (UHC) to carbon IV oxide and water:

$$
\mathrm{C}_{\mathrm{x}} \mathrm{H}_{2 \mathrm{x}+2}+[(3 \mathrm{x}+1) / 2] \mathrm{O}_{2} \rightarrow \mathrm{xCO}_{2}+(\mathrm{x}+1) \mathrm{H}_{2} \mathrm{O} \text {. }
$$

Although catalytic converters are most commonly applied to exhaust system in automobiles, they are also used on electrical generators, forklifts, mining equipment, trucks, buses, locomotives, motorcycles and airplanes. They are also used on some wood stove to control emissions (Coffey, 2006). The composition of the exhaust gases in the combustion of gasoline in an internal combustion engine is quite variable, depending to some extent upon the characteristics of operation, but to a greater extent upon the amount of air supplied per unit of fuel burnt. When a large excess of air is provided, the hydrocarbons of the fuel are completely converted to carbon IV oxide $\left(\mathrm{CO}_{2}\right)$ and water $\left(\mathrm{H}_{2} \mathrm{O}\right)$, and some free oxygen $\left(\mathrm{O}_{2}\right)$ appears in the analysis (Roumegoux, 2006). The nitrogen $\left(\mathrm{N}_{2}\right)$ present in the air used for combustion passes through the process of combustion unchanged and so appears in the final products. When the proportion of air to fuel ratio is decreased, however, the combustion of the carbon is incomplete and carbon II oxide (CO) appears. Likewise, the combustion of hydrogen $\left(\mathrm{H}_{2}\right)$ to water is incomplete and free hydrogen is present in the exhaust products.

\section{METHODOLOGY}

The comparative analysis was basically concerned with gasoline passenger cars of low and high mileages. The direct measurement approach to gasoline car exhaust emission collection was deployed. This work had two major components of execution which are

(i) Vehicle selection and

(ii) Vehicle testing.

The vehicles selected for the testing were dependent on high population of the specific vehicle in the Nigerian market, the predominant use by majority and also on the accessibility of such a vehicle for research. The vehicle models were sourced from Kanu Motors Ltd, Onitsha. About six vehicle models of the same vintage but different categories were taken for testing.

Table 2.1: Test Vehicles and Specifications

\begin{tabular}{|l|l|}
\hline Vehicle category and Mileage & Vehicle Class and Specification \\
\hline SUV A of $112,210 \mathrm{~km}$ mileage & V6 cylinder, 2002 model, 2.4L engine. \\
\hline SUV B of $112,120 \mathrm{Km}$ mileage & V6 cylinder, 2002 model, 2.4L engine. \\
\hline Car A of $112,103 \mathrm{~km}$ mileage & 4 cylinder, 2002 model, 2.0L engine. \\
\hline Car B of $111,400 \mathrm{~km}$ mileage & 4 cylinder, 2002 model, 2.0L engine. \\
\hline SUV C of $15,322 \mathrm{~km}$ mileage & V6 cylinder, 2014 model, 2.4L engine. \\
\hline Car C of $14,824 \mathrm{~km}$ mileage & 4 cylinder, 2014 model, 2.0L engine. \\
\hline
\end{tabular}

The vehicles as selected above were brought for testing. Initially, the vehicles were subjected to the minimum check list like exhaust leak check and none failed. The fuel in the vehicle tank was octane fuel as test fuel. After the minimum check, the vehicles were subjected to exhaust gas emission test using the MotorScan Exhaust Gas Analyzer "Total Gas 8050”.

III. EXPERIMENTAL RESULTS AND DISCUSSION

The average results of the repeated tests at 20seconds interval and varying engine speed are as tabulated. The test was carried out repeatedly for ten times at each selected engine speed, after which the average result was computed as shown in tables 3.1 to 3.6. 
Table 3.1: Summary of the Mean Values of Emission Results from SUV' $A$ '

\begin{tabular}{|c|c|c|c|c|c|c|c|c|}
\hline $\begin{array}{l}\text { Time } \\
(\mathrm{Sec})\end{array}$ & $\begin{array}{l}\text { Engine } \\
\text { RPM }\end{array}$ & $\begin{array}{l}\mathrm{CO} \\
(\%)\end{array}$ & $\begin{array}{l}\mathrm{CO}_{2} \\
(\%)\end{array}$ & $\begin{array}{l}\text { UHC } \\
\text { (PPM) }\end{array}$ & $\begin{array}{l}\mathrm{O}_{2} \\
(\%)\end{array}$ & $\begin{array}{l}\text { NO } \\
(\mathrm{PPM})\end{array}$ & Lambda & $\begin{array}{l}\text { Engine } \\
\text { Temp } \\
\left({ }^{\mathrm{O}} \mathrm{C}\right) \\
\end{array}$ \\
\hline 20 & 1000 & 0.07 & 16.36 & 140.6 & 2.50 & 26.8 & 1.22 & 40.11 \\
\hline 20 & 1500 & 0.09 & 16.86 & 153.8 & 2.26 & 27.6 & 1.11 & 42.50 \\
\hline 20 & 2000 & 0.10 & 18.42 & 205.3 & 1.94 & 30.2 & 1.03 & 44.70 \\
\hline 20 & 2500 & 0.13 & 18.97 & 212.6 & 1.65 & 29.9 & 0.97 & 47.15 \\
\hline 20 & 3000 & 0.16 & 19.54 & 222.5 & 1.36 & 28.7 & 0.88 & 49.17 \\
\hline
\end{tabular}

Table 3.2: Summary of the Mean Values of Emission Results from SUV ' $B$ '

\begin{tabular}{|l|l|l|l|l|l|l|l|l|}
\hline $\begin{array}{l}\text { Time } \\
(\mathrm{Sec})\end{array}$ & $\begin{array}{l}\text { Engine } \\
\text { RPM }\end{array}$ & $\begin{array}{l}\mathrm{CO} \\
(\%)\end{array}$ & $\begin{array}{l}\mathrm{CO}_{2} \\
(\%)\end{array}$ & $\begin{array}{l}\text { UHC } \\
(\mathrm{PPM})\end{array}$ & $\begin{array}{l}\mathrm{O}_{2} \\
(\%)\end{array}$ & $\begin{array}{l}\text { No } \\
(\mathrm{PPM})\end{array}$ & $\begin{array}{l}\text { Lambda } \\
\text { Engine } \\
\text { Temp }\left({ }^{\mathrm{O}} \mathrm{C}\right)\end{array}$ \\
\hline 20 & 1000 & 0.06 & 16.12 & 146.5 & 2.52 & 28.4 & 1.23 & 40.65 \\
\hline 20 & 1500 & 0.09 & 16.81 & 171.1 & 2.28 & 30.9 & 1.13 & 42.4 \\
\hline 20 & 2000 & 0.11 & 18.16 & 200.3 & 2.00 & 31.6 & 1.05 & 44.8 \\
\hline 20 & 2500 & 0.135 & 18.37 & 213.0 & 1.68 & 32.4 & 0.98 & 47.2 \\
\hline
\end{tabular}

Table 3.3: Summary of the Mean Values of Emission Results from Car ' $A$ '

\begin{tabular}{|l|l|l|l|l|l|l|l|l|}
\hline $\begin{array}{l}\text { Time } \\
(\mathrm{Sec})\end{array}$ & $\begin{array}{l}\text { Engine } \\
\text { RPM }\end{array}$ & $\begin{array}{l}\mathrm{CO} \\
(\%)\end{array}$ & $\begin{array}{l}\mathrm{CO}_{2} \\
(\%)\end{array}$ & $\begin{array}{l}\text { UHC } \\
(\mathrm{PPM})\end{array}$ & $\begin{array}{l}\mathrm{O}_{2} \\
(\%)\end{array}$ & $\begin{array}{l}\text { NO } \\
(\mathrm{PPM})\end{array}$ & $\begin{array}{l}\text { Lambda } \\
\text { Engine } \\
\text { Temp } \\
\left({ }^{\mathrm{O}} \mathrm{C}\right)\end{array}$ \\
\hline 20 & 1000 & 0.02 & 10.47 & 120.4 & 2.23 & 24.8 & 1.13 & 36.32 \\
\hline 20 & 1500 & 0.05 & 11.95 & 137.8 & 2.15 & 27.2 & 1.07 & 38.18 \\
\hline 20 & 2000 & 0.06 & 12.96 & 146.3 & 2.08 & 29.5 & 1.05 & 40.89 \\
\hline 20 & 2500 & 0.08 & 13.68 & 153.5 & 1.98 & 31.4 & 1.01 & 43.50 \\
\hline
\end{tabular}

Table 3.4: Summary of the Mean Values of Emission Results from Car ' $B$ '

\begin{tabular}{|c|c|c|c|c|c|c|c|c|}
\hline $\begin{array}{l}\text { Time } \\
(\mathrm{Sec})\end{array}$ & $\begin{array}{l}\text { Engine } \\
\text { RPM }\end{array}$ & $\begin{array}{l}\mathrm{CO} \\
(\%)\end{array}$ & $\begin{array}{l}\mathrm{CO}_{2} \\
(\%)\end{array}$ & $\begin{array}{l}\text { UHC } \\
\text { (PPM) }\end{array}$ & $\begin{array}{l}\mathrm{O}_{2} \\
(\%)\end{array}$ & $\begin{array}{l}\text { NO } \\
(\mathrm{PPM})\end{array}$ & Lambda & $\begin{array}{l}\text { Engine } \\
\text { Temp } \\
\left({ }^{\mathrm{O} C}\right)\end{array}$ \\
\hline 20 & 1000 & 0.02 & 10.44 & 127.3 & 2.21 & 25.3 & 1.12 & 36.73 \\
\hline 20 & 1500 & 0.05 & 11.87 & 131.5 & 2.16 & 26.5 & 1.08 & 38.00 \\
\hline 20 & 2000 & 0.065 & 12.89 & 144.9 & 2.09 & 29.0 & 1.05 & 40.88 \\
\hline 20 & 2500 & 0.08 & 13.70 & 145.4 & 2.00 & 30.7 & 1.02 & 43.47 \\
\hline 20 & 3000 & 0.102 & 13.97 & 148.1 & 1.59 & 34.4 & 0.97 & 46.23 \\
\hline
\end{tabular}

Table 3.5: Summary of the Mean Values of Emission Results from SUV ' $C$ '

\begin{tabular}{|l|l|l|l|l|l|l|l|l|}
\hline $\begin{array}{l}\text { Time } \\
(\mathrm{sec})\end{array}$ & $\begin{array}{l}\text { Engine } \\
\mathrm{RPM}\end{array}$ & $\begin{array}{l}\mathrm{CO} \\
(\%)\end{array}$ & $\begin{array}{l}\mathrm{CO}_{2} \\
(\%)\end{array}$ & $\begin{array}{l}\text { UHC } \\
(\mathrm{PPM})\end{array}$ & $\begin{array}{l}\mathrm{O}_{2} \\
(\%)\end{array}$ & $\begin{array}{l}\text { NOx } \\
(\mathrm{PPM})\end{array}$ & Lambda & $\begin{array}{l}\text { Engine } \\
\text { Temp }\left({ }^{\circ} \mathrm{C}\right)\end{array}$ \\
\hline 20 & 1000 & 0.027 & 15.02 & 18.05 & 3.05 & 9.92 & 1.237 & 42.08 \\
\hline 20 & 1500 & 0.043 & 16.45 & 19.07 & 2.91 & 10.58 & 1.168 & 43.32 \\
\hline 20 & 2000 & 0.062 & 17.81 & 24.31 & 2.83 & 11.77 & 1.101 & 44.28 \\
\hline 20 & 2500 & 0.078 & 19.08 & 25.47 & 2.65 & 12.15 & 1.019 & 46.03 \\
\hline 20 & 3000 & 0.084 & 19.58 & 26.15 & 2.28 & 12.16 & 0.98 & 48.99 \\
\hline
\end{tabular}

Table 3.6: Summary of the Mean Values of Emission Result from Car ' $C$ '

\begin{tabular}{|l|l|l|l|l|l|l|l|l|}
\hline $\begin{array}{l}\text { Time } \\
(\mathrm{sec})\end{array}$ & $\begin{array}{l}\text { Engine } \\
\text { RPM }\end{array}$ & $\begin{array}{l}\mathrm{CO} \\
(\%)\end{array}$ & $\begin{array}{l}\mathrm{CO}_{2} \\
(\%)\end{array}$ & $\begin{array}{l}\mathrm{UHC} \\
(\mathrm{PPM})\end{array}$ & $\begin{array}{l}\mathrm{O}_{2} \\
(\%)\end{array}$ & $\begin{array}{l}\text { NOx } \\
(\mathrm{PPM})\end{array}$ & Lambda & $\begin{array}{l}\text { Engine } \\
\text { Temp }\left({ }^{\circ} \mathrm{C}\right)\end{array}$ \\
\hline 20 & 1000 & 0.020 & 16.04 & 17.88 & 2.93 & 07.97 & 1.11 & 42.12 \\
\hline 20 & 1500 & 0.026 & 16.68 & 18.34 & 2.87 & 08.75 & 1.06 & 42.52 \\
\hline 20 & 2000 & 0.055 & 17.08 & 22.50 & 2.67 & 10.70 & 0.95 & 43.74 \\
\hline 20 & 2500 & 0.057 & 17.31 & 22.97 & 2.54 & 10.90 & 0.92 & 43.96 \\
\hline 20 & 3000 & 0.061 & 17.85 & 23.05 & 2.31 & 11.15 & 0.92 & 45.91 \\
\hline
\end{tabular}


Tables 3.1 to 3.6 show the summary of the mean values of emission results from the vehicles under study. The emission result shows an increase in $\mathrm{CO}$ (from $0.07 \%$ to $0.16 \%, 0.06 \%$ to $0.16 \%, 0.02 \%$ to $0.10 \%$, $0.02 \%$ to $0.102 \%, 0.027 \%$ to $0.084 \%$ and $0.02 \%$ to $0.06 \%$; for SUVs A,B, Cars A,B, SUV C and Car C respectively) $\mathrm{CO}_{2}$ (from $16.36 \%$ to $19.54 \%, 16.12 \%$ to $19.36 \%, 10.47 \%$ to $14.06 \%, 10.44 \%$ to $13.97 \%, 15.02 \%$ to $19.58 \%$ and $16.04 \%$ to $17.85 \%$; for SUVs A, B, Cars A, B, SUV C and Car C respectively), UHC (140.6PPM to $222.5 \mathrm{PPM}$, 146.5PPM to 234.1PPM, 120.4PPM to 162.0PPM, 127.3PPM to 148.1PPM, 18.05PPM to 26.15PPM and 17.88PPM to 23.05PPM for SUVs A, B, Cars A, B, SUV C and Car C respectively) and NOx (26.8PPM to 28.7PPM, 28.4PPM to 35.5PPM, 24.8PPM to 28.8PPM, 25.3PPM to 34.4PPM, 9.92PPM to 12.16PPM and 07.97PPM to 11.15PPM; for SUVs A, B, Cars A, B, SUV C and Car C respectively) as the engine speed increases from 1000rpm-3000rpm with an increase in the engine temperature. The $\mathrm{O}_{2}(2.50 \%$ to $1.36 \%, 2.52 \%$ to $1.37 \%, 2.23 \%$ to $1.57 \%, 2.21 \%$ to $1.59 \%, 3.05 \%$ to $2.28 \%$ and $2.93 \%$ to $2.31 \%$; for SUVs A, B, Cars A, B, SUV C and Car C respectively) emitted decreases as the engine speed increases with a lambda drop.

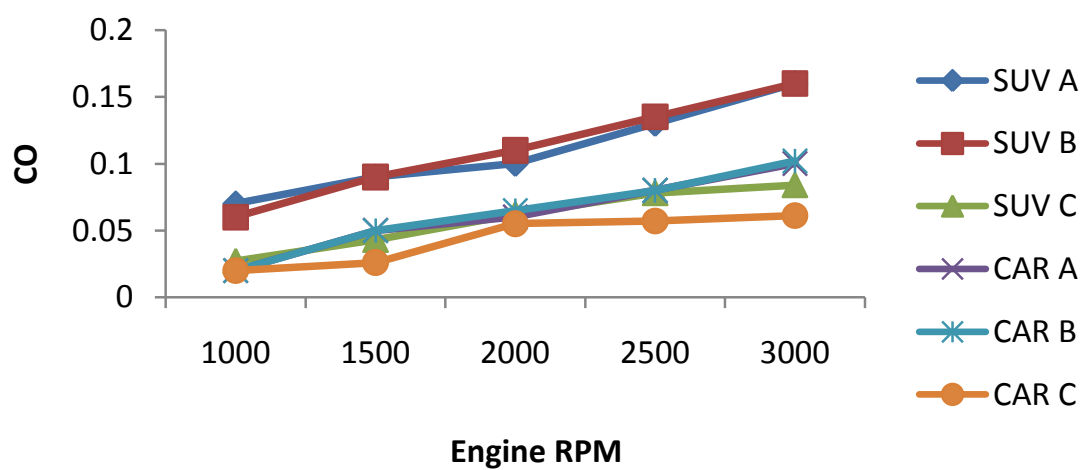

Figure 3.1 Comparison of Carbon II Oxide for High Mileage and Low Mileage Vehicles

Figure 3.1 is the graph that compares Carbon II Oxide obtained from the exhaust gases of both low mileage and high mileage vehicles versus engine RPM. It can be seen that there is increase in CO emitted as the engine revolves from 1000RPM to 3000RPM in all the vehicles. This agrees with the fact that the engine load affects the $\mathrm{CO}$ emitted in both low and high mileage gasoline engines. The graph shows that SUVs A, B and Cars A, B which are of high mileage emit more CO than SUV C and Car C of low mileage. It also shows that SUVs A and B emit more CO than Cars A and B, giving that the capacity of the engine also factored the rate of emission.

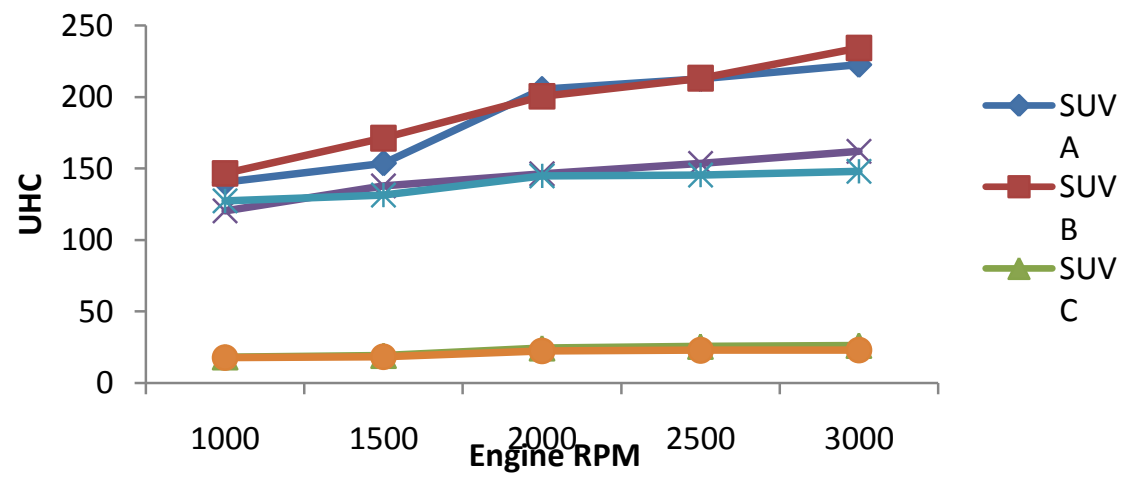

Figure 3.2 Comparison of Unburnt Hydrocarbon for High Mileage and Low Mileage Vehicles

Figure 3.2 is the graph of Unburnt Hydrocarbon obtained from the exhaust gases of both low mileage and high mileage vehicles versus engine RPM. It can be seen that there is increase in UHC emitted as the engine revolves from 1000RPM to 3000RPM in all the vehicles. This suggests that the engine load affects the UHC emitted in both low and high mileage gasoline engines. From the graph, the UHC increases significantly against engine RPM in high mileage vehicles than in low mileage vehicles. The SUVs A and B stood clearly at the top, howing that vehicles with higher capacity engines emit more UHC than lower ones. The effect of engine RPM against the UHC emitted is less than that in CO. 


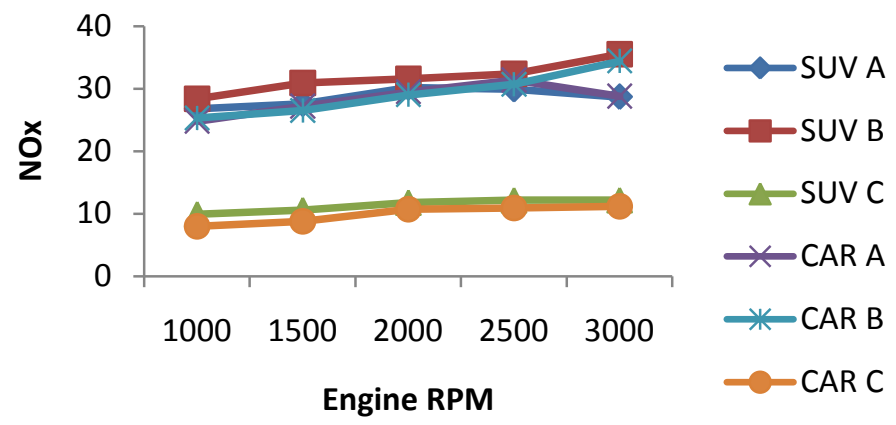

Figure 3.3 Comparison of Nitrogen Oxide for High Mileage and Low Mileage Vehicles

Figure 3.3 is the graph of Nitrogen Oxide obtained from the exhaust gases of both low mileage and high mileage vehicles versus engine RPM. It can be seen that there is increase in Nitrogen oxide emitted as the engine speed moves from 1000RPM to 3000RPM in all the vehicles. This reveals that the engine load affects the NOx emitted in both low and high mileage gasoline engines. From the graph, the NOx increases significantly against engine RPM in high mileage vehicles than in low mileage vehicles. It can be seen that at 3000 engine RPM the NOx tends to drop in some of the vehicles. The effect of engine RPM against the NOx emitted is less when compared to that for $\mathrm{CO}$.

\section{CONCLUSION}

Vehicles play a vital role in our daily life. There is no doubt that automobiles can bring us a tremendous convenience, they impact and shape the world in so many ways. Meanwhile, the emissions from high mileage automobiles also contribute to the air pollution worldwide. These pollutants cause great amount of damages to life and natural environment. It is only apt and absolutely necessary that efforts be made to address the issue of vehicular emissions through strict adherence to national and international standards by all stakeholders. The regulatory body (NESREA) should equally up its game to ensure strict compliance by automobile manufacturers, users and service providers. Efforts should also be geared towards mitigating the adverse consequences of the current level of pollution.

\section{REFERENCES}

[1] Abbaspour, M. and Soltaninejad, A. (2008) "Design of an environmental assessment model on the effect of vehicle emissions". International Journal of Environmental Science Technology.

[2] Ademuyiwa, O. (2009) "Biomarkers of lead exposure in petrol station attendants and auto-mechanics in Abeokuta, Nigeria: effect of 2-week ascorbic acid supplementation". Environmental, Toxicology and Pharmacology.

[3] Ajayi, A. and Dosunmu, O. (2010) "Environmental hazards of importing used vehicles into Nigeria". Proceedings of International Symposium on Environmental Pollution Control and Waste Management.

[4] Kuhns H., Etyemezian V. and Nikolich G. (2007) "Precision and Repeatability of the TRAKER Vehicle-based Paved road Dust Emission Measurement" Desert Research Institute, Division of Atmospheric Sciences, 755 E. USA.

[5] Chan T.L., Ning Z., Leung C.W., Cheung C.S., Hung W.T. and Dong G. (2004) "On-road Remote Sensing of Petrol Vehicle Emissions Measurement and Emission Factors Estimation in Hong Kong”. Atmospheric Environment.

[6] Vijayan A. (2007) "Characterization of Vehicular Exhaust Emissions and Indoor Air Quality of Public Transport Buses Operating on Alternative Diesel Fuels". Ph.D dissertation.

[7] Roumegoux J.P. (2006) "The Science of Total Environment".

[8] Coffey Geosciences (2006) "Fuel Quality and Vehicle Emissions Standards Cost Benefit Analysis prepared for MVEC Review of Vehicle and Fuel Standards Post".

[9] Lave, L.B., Hendrickson, C.T., \& McMichael, F.C. (2007) Environmental Implications of Electric Cars, Science, Vol.268, Iss.5213, pp.993-995.

[10] Light-Duty Automotive Technology and Fuel Economy Trends: 1975-2001; EPA-420-R-01-008; U.S. Environmental Protection Agency, Office of Air and Radiation: Washington, DC, 2001.

[11] Michael P. Walsh. (2010) "Air Pollution: Automobile", The Wiley Encyclopedia of Energy and the Environment, Volume 1; Attilio Bisio, Sharon Boots, editors; New York.

[12] Montzka, S. A., Dlugokencky, E. J., \& Butler, J. H., (2011) Non- $\mathrm{CO}_{2}$ greenhouse gases and climate change, Nature, pp. 43-50. 